\title{
INTERNET DAN INFLASI: CROSS-COUNTRY PANEL ANALYSIS ATAS 5 NEGARA DI ASIA
}

\author{
Anhar Fauzan Priyono \\ Fakultas Ekonomi dan Bisnis Universitas Padjadjaran Bandung \\ Jl. Cimandiri No. 8 Bandung. Telp. 022-4204510 \\ Email: fauzan@fe.unpad.ac.id
}

\begin{abstract}
The objective of this research is to understand the effect of internet utilization, proxied by numbers of internet user to inflation rate. Several other factors are also being considered, which are growth of money supply, exchange rate, and world oil price. There are China, India, Japan, Indonesia, and South Korea, consecutively represent top five countries with the biggest internet users in Asia to be observed. Pooled Least Square with Panel Corrected Standard Error has been employed in terms of analysing inflation's behavior of those countries.

The main finding of this research is that inflation and numbers of internet user are negatively correlated, while the causal effect is statistically not significant. This is most probable, since utilization of internet is still dominated by web surfing, social media, and online games. On the other hand, money supply, exchange rate, and world oil price has a positive relationship with inflation. Those findings are true for all the countries being observed.
\end{abstract}

Keywords: Exchange rate, Inflation, Internet users, Money supply, Panel Corrected Standard Error, Pool Least Square, World oil price.

\section{PENDAHULUAN}

lobalisasi menjadi suatu topik pembicaraan yang cukup sering dibicarakan akhir-akhir ini. Fenomena globalisasi tersebut secara makro, tentunya memiliki dampak positif dan juga negatif. Dampak positif yang dapat ditimbulkan oleh globalisasi diantaranya adalah efisiensi, dimana banyak informasi di suatu tempat dimungkinkan diakses di tempat lain dimanapun juga di dunia ini secara cepat.

QE Journal | Vol.05 - No. 01 March 2016 - 53 
Aksesibilitas dari informasi tersebut tentunya hanya dapat diwujudkan dengan pemanfaatan teknologi informasi yang didukung dengan infrastruktur yang baik di tiap negara. Dengan perkataan lain, diperlukan fasilitas internet yang memadai untuk menjamin aliran informasi tersebut tetap cepat.

Indonesia adalah salah satu dari 10 negara yang terkategori sebagai negara dengan populasi pengguna internet terbesar di kawasan Asia. Negaranegara tersebut seperti diperlihatkan pada Gambar 1.

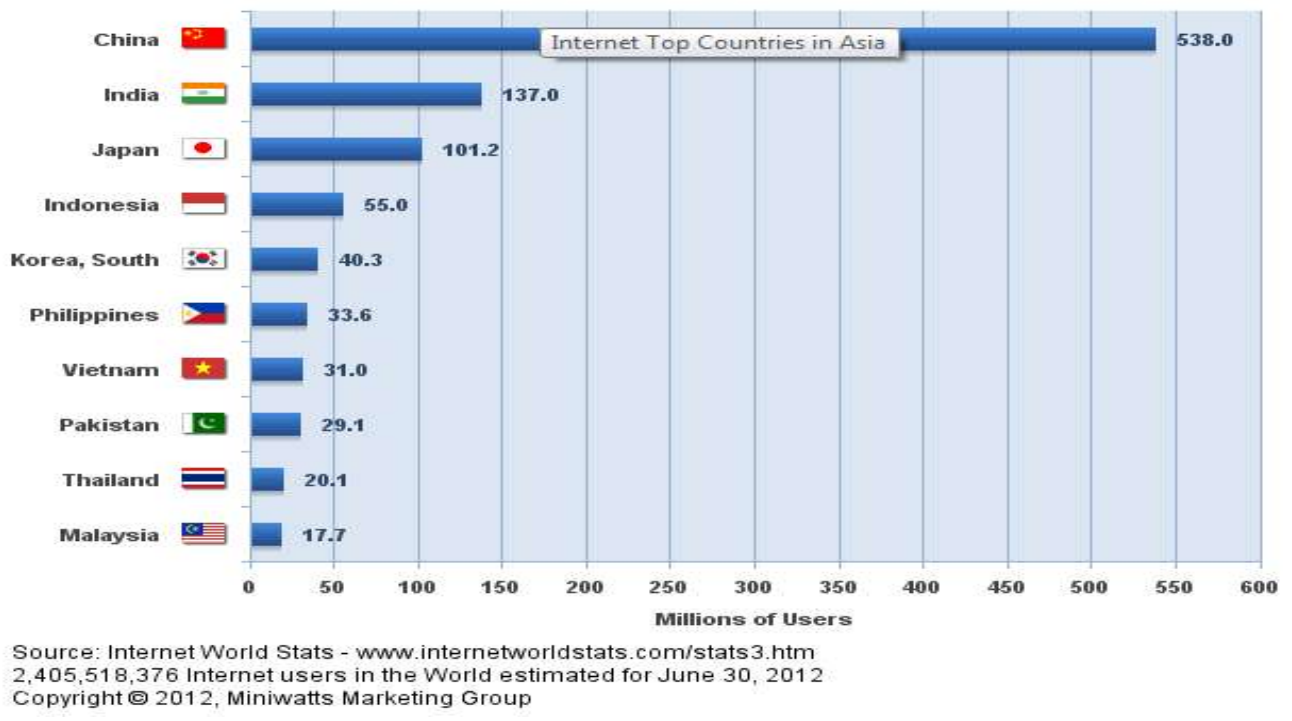

Gambar 1. Asia Top Internet Countries

Apabila dihubungkan dengan faktor makro ekonomi, maka hipotesishipotesis yang dapat ditarik dari pemanfaatan internet adalah meningkatnya tingkat efisiensi, dimana biaya atas barang-barang dapat ditekan, dikarenakan waktu transaksi akan menjadi lebih pendek. Penggunaan internet adalah salah satu proxy yang dapat digunakan untuk mendeterminasi produktivitas dan pertumbuhan ekonomi (Wadhwani, 2000 pp. 44). Selanjutnya Wadhwani (2000) juga menyatakan bahwa internet akan memiliki pengaruh yang signifikan terhadap inflasi.

Beberapa peneliti sebelumnya, telah melakukan penelitian atas determinasi internet ini terhadap beberapa variabel makro ekonomi. Choi (2003), Freund \& Weinhold (2004), melakukan penelitian atas dampak internet 
terhadap perdagangan bilateral dan investasi asing langsung. Sementara Choi \& Yi (2004) melakukan penelitian atas dampak internet terhadap inflasi.

Ketertarikan untuk mengetahui dampak internet terhadap inflasi adalah salah satu variabel yang tergolong indikator utama dalam kinerja perekonomian dari suatu negara. Selanjutnya adalah untuk menjawab pertanyaan mekanisme kemampuan internet dalam mempengaruhi inflasi. Mekanisme tersebut dapat dibangun dari suatu hipotesis, merujuk pada penelitian empiris sebelumnya, salah satunya adalah dalam Litan \& Rilvin (2001) dijelaskan tentang dampak ekonomi dari internet, yaitu mempengaruhi tingkat tabungan dan berbagai benefit lainnya. Sedangkan Choi \& Yi (2004) menemukan bahwa internet dapat mempengaruhi produktivitas dan kemudian dapat menurunkan tingkat inflasi.

Fungsi produksi Cobb-Douglas menyatakan bahwa determinan dari output suatu perusahaan adalah jumlah modal dan tenaga kerja. Secara umum, fungsi produksi ini dapat dituliskan dalam persamaan sebagai berikut:

$Y=A L^{\beta} K^{\alpha}$

dimana: $Y=$ total produksi; $L=$ input tenaga kerja

$$
K=\text { input modal; } A=\text { total factor productivity }
$$

Sedangkan $\alpha$ dan $\beta$ adalah elastisitas dari tiap input produksi dalam persamaan tersebut. Tentunya, apabila mempertimbangkan ketersediaan input produksi, baik dari sisi tenaga kerja maupun modal, maka tambahan peningkatan output produksi hanya dapat dicapai dengan pemanfaatan teknologi. Teknologi selanjutnya dinilai sebagai variabel yang dapat menciptakan efisiensi.

Internet sebagai salah satu bentuk dalam teknologi informasi juga dianggap dapat menciptakan efisiensi dalam ekonomi. Reduksi waktu transaksi menjadi salah satu bentuk efisiensi yang ditimbulkan oleh penggunaan internet, selain dari kemampuannya untuk menyediakan informasi dengan akurat dari berbagai tempat di dunia.

Harga minyak dunia dan inflasi secara umum memiliki hubungan yang searah. Setiap peningkatan dalam harga minyak dunia, berpotensi meningkatkan inflasi. Hal ini disadari sebagai bentuk peranan minyak 
sebagai input utama dalam perekonomian. Dimana, minyak menjadi sumber bahan bakar utama yang dimanfaatkan untuk transportasi dan kebutuhan rumah tangga. Dampak peningkatan harga minyak dunia dapat direfleksikan pada peningkatan biaya produksi, yang selanjutnya dapat meningkatkan harga komoditas.

Peningkatan jumlah uang beredar merupakan salah satu tanda meningkatnya kebutuhan orang akan transaksi. Keynesian economics menjelaskan bahwa motif transaksi menjadi salah satu motif orang memegang uang, selain untuk kebutuhan berjaga-jaga (pre-cautionary), dan spekulasi.

Selanjutnya, dikarenakan statusnya sebagai alat pembayaran yang paling likuid, maka orang akan lebih mudah menggunakan uang untuk transaksi dibandingkan alat pembayaran lainnya, seperti e-money. Dengan semakin meningkatnya transaksi yang dilakukan, sebagai akibat meningkatnya jumlah uang beredar, maka harga-harga komoditas berpotensi untuk meningkat.

Beberapa penelitian terdahulu yang dijadikan rujukan dalam penelitian ini diantaranya adalah seperti yang dilakukan oleh Oliner \& Sichel (2000, 2003) yang menemukan bahwa penggunaan informasi yang lebih banyak sebagai dampak pemanfaatan teknologi informasi, dapat mendorong pertumbuhan produktivitas di Amerika Serikat setelah tahun 1995.

Dilain pihak, Salvatore (2003) menyatakan bahwa liberalisasi dalam ekonomi, termasuk didalamnya restrukturisasi teknologi informasi dan komunikasi, merupakan faktor penting menuju sistem perekonomian baru yang lebih terpadu. Choi (2003), dan Freund \& Weinhold (2004) melakukan suatu riset yang meneliti tentang dampak internet terhadap beberapa variabel ekonomi, yaitu perdagangan bilateral dan investasi asing langsung.

Choi \& Yi (2004) menemukan bahwa internet secara signifikan mempengaruhi tingkat inflasi. Dalam penelitian ini ditemukan bahwa peningkatan pengguna internet sebagai proxy dari pemanfaatan teknologi informasi berkorelasi erat dengan menurunnya tingkat inflasi

Dengan didasarkan paparan yang telah disebutkan sebelumnya, maka pokok-pokok permasalahan yang akan dianalisis dan kemudian dicari jawabannya dalam penelitian ini adalah sebagai berikut: (1) Dalam era

QE Journal | Vol.05 - No. 01 March 2016 - 56 
globalisasi ini, apakah internet dapat memengaruhi pergerakan inflasi dari suatu negara? (2) Apakah jumlah uang beredar dari sisi permintaan akan uang dapat memengaruhi tingkat inflasi dari suatu negara? (3) Apakah nilai tukar dapat memengaruhi tingkat inflasi dari suatu negara? (4) Dikarenakan masih dimanfaatkannya bahan bakar fosil sebagai sumber energi, maka apakah harga minyak dunia dapat memengaruhi tingkat inflasi dari suatu negara.

\section{METODE PENELITIAN}

Penelitian ini akan memanfaatkan analisis kuantitatif untuk mengetahui dampak inflasi dan beberapa variabel makro terhadap pergerakan inflasi di 5 negara yang memiliki pengguna internet terbesar di Asia. Periode waktu yang dipilih adalah tahun 2001 - 2011, dengan frekuensi data tahunan.

Teknik estimasi yang akan dipergunakan adalah berbasis data panel, yaitu Pool Ordinary Least Square (POLS) - Panel Corrected Standard Error (PCSE). Persamaan ekonometrika yang kemudian akan diestimasi adalah sebagai berikut:

Inf $_{i t}=\gamma_{0}+\gamma_{1}$ Int $_{i t}+\gamma_{2} E R_{i t}+\gamma_{3} M S_{i t}+\gamma_{4} O i l_{t}+v_{i t}$

dimana:

Inf $_{\boldsymbol{i t}}=$ inflasi (pertumbuhan IHK) negara i pada periode $k e-t$

Int $_{i t}=$ jumlah penduduk dengan akses internet negara $i$ periode $k e-t$

$\boldsymbol{E}_{\boldsymbol{i t}}=$ nilai tukar negara $i$ terhadap US Dollar periode $k e-t$

$\boldsymbol{M S}_{\boldsymbol{i t}}=$ pertumbuhan jumlah uang beredar negara $i$ periode $k e-t$

Oil $_{\boldsymbol{t}}=$ harga minyak dunia (US Dollar per barrel)periode $k e-t$

$v_{i t}$

$=$ terdistribusi secara independen dan identik antar negara dan waktu

Deskripsi atas tiap variabel yang dipergunakan adalah: (1) Inflasi adalah pertumbuhan dari Indeks Harga Konsumen, yang diperoleh dari World Development Index (WDI) - World Bank; (2) Internet adalah jumlah pengguna internet (memiliki akses internet), yang diperoleh dari World Development Index (WDI) - World Bank; (3) Nilai tukar adalah nilai kurs mata uang domestik terhadap US Dollar, yang diperoleh dari Pacific 
Exchange Rate Service - The University of British Columbia; (4) Pertumbuhan jumlah uang beredar adalah pertumbuhan dari base money dan quasi money, yang diperoleh dari World Development Index (WDI) World Bank; (5) Harga minyak dunia adalah harga minyak mentah (crude oil) dunia, US Dollar per barrel, yang diperoleh dari Index Mundi.

\section{HASIL DAN PEMBAHASAN}

Hasil estimasi pemodelan inflasi dengan determinannya adalah jumlah pengguna internet, nilai tukar, jumlah uang beredar, dan harga minyak dunia, adalah sebagai berikut (t-statistik dalam kurung):

$$
\begin{aligned}
& \mathbf{E}\left(\operatorname{Inf}_{\text {it }}\right)=0,99-3,41 * 10^{-9} \text { Int }_{\text {it }}+0,0005 E R_{\text {it }}+0,18 \mathrm{MS}_{\text {it }}+0,0030 \mathrm{il}_{\mathrm{t}} \\
& (-0,66) \quad\left(3,89^{* * *}\right) \quad\left(4,12^{* * *}\right) \quad(0,21)
\end{aligned}
$$

$\mathrm{R}^{2}=0.48 ;$ F-stat $=11,73^{* * *}$

Keterangan: ${ }^{* * *}$ adalah signifikan pada tingkat kepercayaan $99 \%$

Variasi pergerakan tingkat inflasi rata-rata secara agregat untuk kelima negara (China, India, Jepang, Indonesia, dan Korea Selatan) tersebut dapat dideterminasi oleh jumlah pengguna internet (INT), nilai tukar (ER), dan jumlah uang beredar (MS) di tiap negara, serta harga minyak mentah dunia (OIL) sebesar $48 \%$. Secara simultan, keempat variabel independen tersebut signifikan mempengaruhi variasi pergerakan inflasi.

Jumlah pengguna internet memiliki korelasi yang negatif dengan tingkat inflasi, yang telah sesuai dengan hipotesis atas konsep efisiensi yang ditimbulkan atas pemanfaatan teknologi dalam mempengaruhi harga komoditas. Namun, koefisien variabel jumlah pengguna internet tersebut tidak signifikan secara statistik.

Harga minyak mentah dunia juga memperlihatkan keselarasan hipotesis atas konsep peningkatan biaya operasional perusahaan yang akan memengaruhi harga komoditas. Hal tersebut dapat dilihat dari tanda koefisiennya, namun, pengaruhnya adalah tidak signifikan terhadap tingkat inflasi.

Dari hasil estimasi, hanya ditemukan nilai tukar dan jumlah uang beredar yang memiliki pengaruh yang signifikan terhadap tingkat inflasi. Hal ini sesuai dengan hipotesis awal, baik untuk nilai tukar, maupun jumlah uang beredar. 
Estimasi yang telah dilakukan diatas memanfaatkan teknik Pooled Ordinary Least Square (POLS) dengan Panel Corrected Standard Error (PCSE). Dalam Witkowska (2006), dijelaskan bahwa diperlukan asumsi yang sangat kuat terkait error term pada estimasi data panel, baik dengan metode Fixed Effect, maupun Random Effect. Witkowska (2006) melakukan penelitian tentang hubungan antara faktor fundamental dengan stock return, memanfaatkan analisis data panel. Dalam penelitiannya, validitas dari error term perlu dikaji dengan mendalam, terkait kemungkinan adanya permasalahan serial korelasi, dan/atau heteroskedastisitas.

Apabila error term dalam estimasi data panel memiliki permasalahan serial korelasi dan heteroskedastisitas, maka parameter yang dihasilkan Fixed Effect dan Random Effect akan kehilangan efektivitas dan menjadi bias. Park (1967) menyarankan penggunaan aplikasi Generalised Least Squares (GLS). Namun, teknik tersebut membutuhkan transformasi data memanfaatkan error covariance matrix. Di lain pihak, Beck \& Katz (1995) menyarankan penggunaan estimasi parameter-parameter dengan model yang dikembangkan oleh Prais-Winsten, kemudian melakukan penyesuaian pada standard error dalam panel data.

Penyesuaian standard error tersebut dilakukan dalam skema Panel Corrected Standard Error (PCSE) yang dihitung dengan memanfaatkan formula sebagai berikut:

$$
\operatorname{Var}\left\{\widehat{\boldsymbol{\beta}}_{P C S E}\right\}=\left(\boldsymbol{X}^{\prime} \boldsymbol{X}\right)^{-\mathbf{1}} \boldsymbol{X}^{\prime} \boldsymbol{\Omega} \boldsymbol{X}\left(\boldsymbol{X}^{\prime} \boldsymbol{X}\right)^{-\mathbf{1}}
$$

Matriks X merepresentasikan explanatory variables, dimana $\boldsymbol{\Omega}$ adalah matriks kovarians untuk seluruh error term. Selanjutnya dalam Witkowska (2006) dijelaskan pula bahwa teknik Panel Corrected Standar Error (PCSE) ini dapat mengeliminasi permasalahan heteroskedastisitas, serial korelasi, dan korelasi antar individu dalam sistem panel.

\section{SIMPULAN DAN SARAN}

Peningkatan jumlah pengguna internet selama periode tahun 2001 - 2011, di lima negara Asia pengguna internet terbesar, tidak secara signifikan mempengaruhi penurunan tingkat inflasi di kelima negara tersebut. Hal ini disadari sebagai bentuk dari kecenderungan peningkatan penggunaan internet yang belum berbasis pembelian komoditas, namun untuk keperluan jejaring sosial. Sehingga, penggunaan internet yang kemudian 
dapat berdampak pada efisiensi dari biaya komoditas belum dapat diwujudkan.

Dari sisi konsep makroekonomi, dapat disimpulkan bahwa nilai tukar yang terdepresiasi cenderung meningkatkan tingkat inflasi. Hal ini didasarkan pada fakta bahwa dalam skema perekonomian terbuka (open economy), kebutuhan atas barang impor, baik dalam bentuk barang modal maupun barang konsumsi, belum dapat dihindari. Oleh karenanya, semakin terdepresiasi nilai tukar, akan memaksa produsen untuk meningkatkan harga jual produknya (atas barang impor di dalam negeri), yang kemudian akan berdampak pada peningkatan inflasi. Di lain pihak, jumlah uang beredar juga secara signifikan mempengaruhi peningkatan inflasi. Hal ini didasarkan atas uang adalah sarana transaksi yang paling likuid, sehingga dapat memotivasi orang untuk melakukan transaksi. Dengan meningkatnya permintaan komoditas, maka harga barang dapat meningkat. Kondisi seperti ini sesuai dengan the quantity theory of money, dimana tingkat harga adalah, salah satunya, merupakan fungsi dari jumlah uang beredar, dengan korelasi positif.

Hal lain yang dapat disimpulkan dari penelitian ini adalah, bahwa, terdapat korelasi positif antara harga minyak mentah dunia dengan tingkat inflasi. Namun, tidak dapat ditemukan pengaruh secara signifikan dari peningkatan harga minyak mentah dunia terhadap tingkat inflasi. Hal ini menjadi indikasi efektivitas perusahaan dalam melakukan distribusi komoditas, yang membutuhkan bahan bakar, khususnya bahan bakar fosil. Peningkatan harga dimungkinkan terjadi, namun tidak signifikan.

Internet merupakan sarana yang memungkinkan pertukaran informasi terjadi antar tempat yang berbeda dan berjauhan secara cepat. Pemanfaatan internet seharusnya tidak hanya dilakukan untuk komunikasi semata, namun juga dimanfaatkan untuk peningkatan wawasan pengetahuan (contohnya research and development), dan khususnya sebagai media transaksi untuk efisiensi biaya.

Pemerintah dapat melakukan sosialisasi tentang penggunaan internet yang efektif untuk kemajuan perekonomian dalam negeri, tidak hanya semata dimanfaatkan untuk kegiatan-kegiatan jejaring sosial, dan permainan.

\section{DAFTAR PUSTAKA}

QE Journal | Vol.05 - No. 01 March 2016 - 60 
Beck, N \& Katz, J. (1995). What to do (and not to do) with time series cross section data. American Political Science Review, 89.

Choi, C. (2003). Does the Internet stimulate inward FDI? Journal of Policy Modeling, 25, 319-326.

Choi, C \& Yi, M. H. (2004). The effect of the internet on inflation: Panel data evidence. Journal of Policy Modeling 27 (2005) 885-889

Freund, C., \& Weinhold, D. (2004). The effect of the Internet on international trade. Journal of International Economics, 62, 171-189.

Index Mundi, http://www.indexmundi.com/commodities/.

Litan, R. E., \& Rilvin, A. M. (2001). Projecting the economic impact of the Internet. American Economic Review, 91, 313-317.

Oliner, S. D., \& Sichel, D. E. (2000). The resurgence of growth in the late 1990s: Is information technology the story? Journal of Economic Perspectives, 14, 3-22.

Oliner, S. D., \& Sichel, D. E. (2003). Information technology and productivity: Where are we now and where are we going? Journal of Policy Modeling, 25, 477-503.

Parks, R. (1967). Efficient estimation of a system of regression equations when disturbances are both serially and contemporaneously correlated. Journal of the American Statistical Association, 62.

Salvatore, D. (2003). The NewEconomy and growth in the G-7 countries. Journal of Policy Modeling, 25, 531-540.

The University of British Columbia, Pacific Exchange Rates Service.

Wadhwani, S. B. (2000). The impact of the Internet on UK inflation. Bank of England Quarterly Bulletin, Bank of England: 184-198

Witkowska, M. (2006). Fundamentals and stock returns on the Warsaw Stock Exchange. The application of panel data models. Warsaw School of Economics - Institute of Econometrics. 


\section{Lampiran.}

Tabel 1. Statistik Deskriptif Inflasi - INF (China, India, Jepang, Indonesia, dan Korea Selatan)

\begin{tabular}{lccccc}
\hline & INF_CHN & INF_IND & INF_JAP & INF_INA & INF_KOR \\
\hline Mean & 2.447181 & 6.590121 & -0.264546 & 8.296298 & 3.259315 \\
Median & 1.821648 & 6.145522 & -0.273111 & 6.585719 & 2.955863 \\
Maximum & 5.864384 & 11.99230 & 1.373490 & 13.10942 & 4.674315 \\
Minimum & -0.765949 & 3.684807 & -1.346719 & 4.813524 & 2.241726 \\
Std. Dev. & 2.341574 & 3.009022 & 0.719781 & 3.075668 & 0.760563 \\
Skewness & 0.072383 & 0.621308 & 0.787535 & 0.302817 & 0.471745 \\
Kurtosis & 1.698654 & 1.977830 & 3.664208 & 1.468102 & 2.070352 \\
& & & & & \\
Jarque-Bera & 0.785793 & 1.186592 & 1.339259 & 1.243689 & 0.804109 \\
Probability & 0.675098 & 0.552503 & 0.511898 & 0.536953 & 0.668944 \\
& & & & & \\
Sum & 26.91899 & 72.49133 & -2.910008 & 91.25927 & 35.85246 \\
Sum Sq. Dev. & 54.82970 & 90.54215 & 5.180852 & 94.59732 & 5.784560 \\
& & & & & \\
Observations & 11 & 11 & 11 & 11 & 11 \\
\hline
\end{tabular}

Keterangan: Jarque-Bera stat menunjukkan bahwa tiap data memiliki distribusi normal

Tabel 2. Statistik Deskriptif Pengguna Internet - INT (China, India, Jepang, Indonesia, dan Korea Selatan)

\begin{tabular}{lccccc}
\hline & INT_CHN & INT_IND & INT_JAP & INT_INA & INT_KOR \\
\hline Mean & $2.03 \mathrm{E}+08$ & 60072727 & 83205198 & 21445455 & 35970081 \\
Median & $1.37 \mathrm{E}+08$ & 42000000 & 87749554 & 20000000 & 37778532 \\
Maximum & $5.13 \mathrm{E}+08$ & $1.37 \mathrm{E}+08$ & $1.02 \mathrm{E}+08$ & 55000000 & 41714802 \\
Minimum & 33700000 & 7000000. & 48993130 & 4200000. & 26804062 \\
Std. Dev. & $1.65 \mathrm{E}+08$ & 44212489 & 18486615 & 15932192 & 5170996. \\
Skewness & 0.777422 & 0.597762 & -0.735423 & 0.867906 & -0.635221 \\
Kurtosis & 2.119165 & 2.001429 & 2.079874 & 2.846237 & 2.069909 \\
& & & & & \\
Jarque-Bera & 1.463647 & 1.112109 & 1.379592 & 1.391814 & 1.136251 \\
Probability & 0.481031 & 0.573467 & 0.501678 & 0.498622 & 0.566587 \\
& & & & & \\
Sum & $2.23 \mathrm{E}+09$ & $6.61 \mathrm{E}+08$ & $9.15 \mathrm{E}+08$ & $2.36 \mathrm{E}+08$ & $3.96 \mathrm{E}+08$ \\
Sum Sq. Dev. & $2.74 \mathrm{E}+17$ & $1.95 \mathrm{E}+16$ & $3.42 \mathrm{E}+15$ & $2.54 \mathrm{E}+15$ & $2.67 \mathrm{E}+14$ \\
& & & & & \\
Observations & 11 & 11 & 11 & 11 & 11 \\
\hline
\end{tabular}

Keterangan: Jarque-Bera stat menunjukkan bahwa tiap data memiliki distribusi normal

QE Journal | Vol.05 - No. 01 March 2016 - 62 
Tabel 3. Statistik Deskriptif Nilai Tukar terhadap US Dollar - ER (China, India, Jepang, Indonesia, dan Korea Selatan)

\begin{tabular}{lccccc}
\hline & ER_CHN & ER_IND & ER_JAP & ER_INA & ER_KOR \\
\hline Mean & 7.550355 & 46.12927 & 104.6628 & 9450.664 & 1130.353 \\
Median & 7.822000 & 45.60100 & 107.7570 & 9224.600 & 1148.100 \\
Maximum & 8.277300 & 52.37800 & 127.3810 & 11213.70 & 1362.140 \\
Minimum & 6.350000 & 39.36300 & 77.80300 & 8488.100 & 925.1200 \\
Std. Dev. & 0.758383 & 3.271738 & 16.76424 & 754.1121 & 137.3850 \\
Skewness & -0.357483 & -0.167424 & -0.284519 & 1.189708 & -0.056192 \\
Kurtosis & 1.476508 & 3.563006 & 1.713459 & 3.794869 & 2.175502 \\
& & & & & \\
Jarque-Bera & 1.298094 & $\mathbf{0 . 1 9 6 6 7 0}$ & $\mathbf{0 . 9 0 7 0 3 7}$ & $\mathbf{2 . 8 8 4 4 9 0}$ & $\mathbf{0 . 3 1 7 3 6 2}$ \\
Probability & 0.522544 & 0.906345 & 0.635388 & 0.236396 & 0.853268 \\
& & & & & \\
Sum & 83.05390 & 507.4220 & 1151.291 & 103957.3 & 12433.88 \\
Sum Sq. Dev. & 5.751450 & 107.0427 & 2810.398 & 5686851. & 188746.3 \\
& & & & & 11 \\
Observations & 11 & 11 & 11 & 11 \\
\hline Keterangan: Jarque-Bera stat menunjukkan bahwa tiap data memiliki distribusi normal
\end{tabular}

Keterangan: Jarque-Bera stat menunjukkan bahwa tiap data memiliki distribusi normal

Tabel 4. Statistik Deskriptif Pertumbuhan Jumlah Uang Beredar - MS (China, India, Jepang, Indonesia, dan Korea Selatan)

\begin{tabular}{lccccc}
\hline & MS_CHN & MS_IND & MS_JAP & MS_INA & MS_KOR \\
\hline Mean & 18.21596 & 17.52573 & -0.635605 & 13.09317 & 8.176523 \\
Median & 17.32297 & 16.76116 & 0.703240 & 14.92287 & 8.923779 \\
Maximum & 28.42328 & 22.27150 & 2.919237 & 19.32512 & 15.93772 \\
Minimum & 13.14044 & 13.03361 & -17.13713 & 4.761175 & -0.642333 \\
Std. Dev. & 4.162383 & 2.929343 & 5.557117 & 4.320776 & 5.803100 \\
Skewness & 1.334278 & 0.284360 & -2.688622 & -0.579507 & -0.203217 \\
Kurtosis & 4.392472 & 2.092357 & 8.583688 & 2.389109 & 1.679692 \\
& & & & & \\
Jarque-Bera & $\mathbf{4 . 1 5 2 5 7 6}$ & $\mathbf{0 . 5 2 5 8 2 7}$ & 27.54232 & $\mathbf{0 . 7 8 6 7 3 0}$ & $\mathbf{0 . 8 7 4 6 8 4}$ \\
Probability & 0.125395 & 0.768808 & 0.000001 & 0.674782 & 0.645750 \\
& & & & & \\
Sum & 200.3755 & 192.7830 & -6.991657 & 144.0249 & 89.94175 \\
Sum Sq. Dev. & 173.2543 & 85.81051 & 308.8155 & 186.6911 & 336.7597 \\
& & & & & 11 \\
Observations & 11 & 11 & 11 & 11 \\
\hline Keterangan: Jarque-Bera stat menunjukkan bahwa tiap data memiliki distribusi normal (kecuali Jepang)
\end{tabular}

QE Journal | Vol.05 - No. 01 March 2016 - 63 
Tabel 5. Statistik Deskriptif Harga Minyak Mentah Dunia - OIL

\begin{tabular}{lc}
\hline & OlL \\
\hline Mean & 57.55364 \\
Median & 56.47000 \\
Maximum & 104.2600 \\
Minimum & 18.52000 \\
Std. Dev. & 28.86405 \\
Skewness & 0.248093 \\
Kurtosis & 1.720725 \\
& \\
Jarque-Bera & 0.862925 \\
Probability & 0.649558 \\
& \\
Sum & 633.0900 \\
Sum Sq. Dev. & 8331.335 \\
Observations & 11 \\
\hline Keterangan: Jarque-Bera stat menunjukkan bahwa data memiliki distribusi normal
\end{tabular}

